\title{
Oil prices drop effect on construction industry in Kuwait
}

\author{
Hashem Al-Tabtabai**** and Ehab Soliman* \\ * Civil Engineering Department, Kuwait University, Kuwait \\ **Correspondent Author: h.tabtabai@ku.edu.kw
}

Submitted : 24/02/2021

Revised :24/08/2021

Accepted :05/09/2021

\begin{abstract}
The oil price has fallen significantly from its peak at $\$ 128.14$ per barrel in March 2012, reaching a low of \$29 in February 2016. Kuwait depends mainly on oil revenue to finance infrastructure governmental projects. Oil price decline has a direct impact on economic and capital expenditure in the construction industry's resources in Kuwait, specifically construction material. This research investigates the effect of changes in oil prices over the range 20072017 on the construction industry in Kuwait. Different types of data regarding global economic data, construction materials, and awarded contracts during the study period were gathered and analyzed. A set of statistical and correlation analyses are performed. The study revealed that many construction materials are affected by oil price in Kuwait. The GDP is highly affected by oil price drop; this implies that there is a limited result of government plans to diverse governmental finance. A regression model is proposed to forecast the construction cost per square meter in Kuwaiti dinar based on study variables. The study results can be used to evaluate the effect of oil price drop in similar construction environments such as Gulf countries and to predict construction costs changes due to oil price decline.
\end{abstract}

Keywords: Construction management; Oil prices; Construction industry; Regression.

\section{INTRODUCTION}

The Gulf countries are classified as a part of the developing countries. The construction industry plays an important function for Gulf countries, where the oil production has enlarged, and countries revenues have risen for many decades. This huge amount of money led to the availability of enormous funds that Gulf leaders have invested in enormous developments such as the construction industry (Alzayani, 2012).

Kuwait, as one of the Gulf countries, is heavily reliant on oil to fund its governmental plans. In the year of 2013, the hydrocarbon industry accounted for $55.9 \%$ of total output and $95 \%$ of total government revenue (CSB 2012). Fluctuations in oil price undoubtedly have a direct impact on gross domestic product (GDP). Both government and private sectors' consumption expenditure in 2013 accounted for about 41 percent of GDP. The net exports and fixed capital formation represent the remaining 45 percent and 14 percent, respectively. Many financial professionals projected that the recent drop in the oil price does not essentially suggest lesser consumption in the domestic economy (Institute of Banking Studies 2015). 
As resulting from the economical parameters shown in Table 1, the non-oil sector economic activity has been affected by oil price declination, but it is expected to enhance during the coming years. Non-oil growth slowed from $4.9 \%$ in 2014 to $1.4 \%$ in 2016 and then started growth slightly after that. Non-oil GDP growth elevated to 3 $\%$ in 2019 in Kuwait and increased afterward as specified in a recent International Monetary Fund report about Kuwait (IMF 2019).

Table 1. Chosen Economic Indicators for Kuwait: 2014-2024.

\begin{tabular}{|c|c|c|c|c|c|c|c|c|c|c|c|}
\hline & & & & & & \multicolumn{6}{|c|}{ Projections } \\
\hline & 2014 & 2015 & 2016 & 2017 & 2018 & 2019 & 2020 & 2021 & 2022 & 2023 & 2024 \\
\hline \multicolumn{12}{|c|}{ Oil and gas sector } \\
\hline $\begin{array}{l}\text { Total oil \& gas exports } \\
\text { (billions \$) }\end{array}$ & 97.6 & 48.5 & 41.5 & 49.6 & 65.7 & 58.3 & 59.6 & 60.2 & 60.9 & 62.1 & 63.3 \\
\hline Average oil export price (\$/barrel) & 96.5 & 49 & 41 & 53.4 & 70.6 & 61.5 & 61.4 & 60.6 & 60.1 & 60.2 & 60.6 \\
\hline $\begin{array}{l}\text { Crude oil production } \\
\text { (millions of barrels/day) }\end{array}$ & 2.87 & 2.86 & 2.95 & 2.7 & 2.74 & 2.79 & 2.86 & 2.93 & 2.99 & 3.05 & 3.11 \\
\hline $\begin{array}{l}\text { Nominal GDP (market prices, in } \\
\text { billions of Kuwaiti dinar) }\end{array}$ & 46.0 & 34.0 & 33.0 & 36.0 & 43.0 & 41.0 & 43.0 & 45.0 & 47.0 & 49.0 & 52.0 \\
\hline $\begin{array}{c}\text { Nominal GDP } \\
\text { (market prices, in billions of \$) }\end{array}$ & 163.0 & 115.0 & 109.0 & 120.0 & 141.0 & 137.0 & 143.0 & 150.0 & 156.0 & 163.0 & 172.0 \\
\hline Real GDP & 0.5 & 0.6 & 2.9 & -3.5 & 1.7 & 2.5 & 2.9 & 2.9 & 2.5 & 2.7 & 2.9 \\
\hline Real oil GDP & -2.1 & -1.7 & 3.9 & -7.2 & 1.2 & 2.0 & 2.5 & 2.5 & 2.0 & 2.0 & 2.0 \\
\hline Real non-oil GDP & 4.9 & 4.2 & 1.4 & 2.1 & 2.5 & 3.0 & 3.5 & 3.6 & 3.6 & 3.7 & 4.0 \\
\hline CPI inflation (average) & 3.1 & 3.7 & 3.5 & 1.5 & 0.7 & 2.5 & 2.7 & 4.7 & 3.9 & 3.0 & 3.0 \\
\hline
\end{tabular}

Source IMF Special report on Kuwait (2019)

The government of Kuwait had lately embraced the Kuwait Development Plan that aims to support a remarkable growth in real non-oil GDP development to $3 \%$ in 2017 and $4 \%$ thereafter. Regional economic aspects are impacted by sluggish in construction and infrastructure project implementation, unbalanced global financial conditions, and concerns from increasing regional security risks (IMF 2019). The GDP of Kuwait and its partners of the GCC countries grow to $3.7 \%$ in 2016 and 2017. This growth rate is considered unexpectedly praiseworthy compared to other emerging markets but remains below the recorded region's average growth rate of $5.8 \%$ between 2000 and 2011. 
Activities of construction industry played a very significant role for both private and public sectors in Kuwait. Oil price and governmental oil returns highly affect Kuwait governmental expenditure in construction on the public sector.

The variation of oil price affects the construction industry in oil-producing countries, which mainly depend on crude oil selling. For example, many studies have been conducted in Nigeria to evaluate the effect of oil price instability in the Nigerian construction industry. In a study that evaluated oil price fluctuation in construction costs in Nigeria, Olatunji (2015) discussed the influence of oil price fluctuation on construction cost in Nigeria. The study showed the rise of construction cost because of the high finance cost due to oil price regimes resistances. The study proposed a mathematical model to predict construction costs based on crude oil shock and other macro variability indices. Osigwe (2015) evaluated the impact of plenty existence of oil sources on the building and investment on construction sector in Nigeria. He concluded that availability of such resources has a positive but insignificant effect on construction investment in Nigeria. Okoye et al. (2016) studied the impact of economic instabilities on the construction sector growth and performance in Nigeria. Their study showed a relationship between the construction sector recorded GDP, but the construction sector growth rate is more unstable compared to that of GDP. Another study by Okoye et al. (2018) showed the interrelationship between oil prices, the Nigerian gross domestic product (GDP), and the construction sector. They revealed that there are very strong positive and significant correlations between total GDP output and the construction sector output. There is a strong significant correlation between the construction sector output and oil prices and between the total GDP output and oil prices. These strong relationships do not have a consequence in any direct causal effect on each other. This implies that economic activities other than the major non-oil sectors encourage the construction activities in Nigeria. Olanrewaju et al. (2018) examined the economic recession causes and their effect on the construction industry. They revealed that the economic recession harms the Nigerian construction industry. This economic recession is a direct result of the crude oil price drop. This effect resulted in high rate of bankruptcy, high rate of unemployment, and mortgage rental rate reduction.

Even for non-oil producers' countries, in Singapore for example, a study resulted that oil price fluctuation can differently affect key project stakeholders. Oil price fluctuation has a greater impact on buildings costs, especially with steel structure systems. They recommend if construction companies tended to stay competitive under oil price fluctuation, companies will carry out their construction processes efficiently (Hwang, 2013).

In Malaysia, Shaari et al. (2013) discussed oil price fluctuation in the influence of Malaysian economic sectors. They concluded that the construction sector was found to be one of the economic sectors highly affected by oil prices changes. Thorbecke (2019) discussed the effect of oil price on many of economic sectors in east and south Asia countries. He found that construction activities are exposed to oil price increases. Oil price increase is reflected on the cost of construction buildings electricity and increasing cost of material transportation and the used construction machinery.

Although the gulf area contains the most important producers of crude oil in the world, there is no or limited research work conducted to evaluate crude oil fluctuation in construction and infrastructure sector. There is lack or no research that had investigated the influence of oil price decline or instability on the economy and expenditure of the government on the construction sector in Kuwait.

This study aims to evaluate the effect of oil price instability on construction material prices and then predict construction industry trends in Kuwait. The significance of this study arises to the point that low oil prices will force-lead to a restriction or decrease in government projects expenditures and certainly reducing spending in the private sector. Generally, the research can be used to forecast the impact of oil price declination on Kuwait construction industry for the next years. 


\section{LITERATURE REVIEW}

\section{Oil Price and GCC Construction Industry}

Gulf countries are mainly oil producers and depend on revenue coming from crude oil exports for governmental expenditure. The GCC countries have taken many major steps aiming to diversify countries' incomes away from oil and gas for the past five decades (Hvidt, 2013). While all the GCC countries tried to apply a policy of reducing their dependency on oil and gas incomes by diversifying their economies, the success of this policy has changed from a country to another. Bahrain and Oman, with the lowest oil and gas reserves diversification, become a more pressing issue (Cherif and Hasanov, 2014).

Construction industry sector in the Middle East, especially in gulf cooperation council countries (GCC), is directly linked to crude oil prices. The declining in oil prices made GCC countries restrict states spending, hampering the growth of the construction industry, which is essentially dependent on government funding (Deloitte report, 2018). In the Middle East countries, capital projects and infrastructure projects have been greatly impacted by lower oil prices, resulting in slowdowns and delays in governmental new projects finance according to a report by PwC (2016).

For a continuous period of unpredictable oil prices, project companies could make massive losses and may be forced to postpone or shut down their activities (Rowland, Christopher and James, Mjelde 212). It is, therefore, safe to say that when the oil prices are low, the government is less assertive in the decision-making process and is less willing to award construction contracts

In 2015, there was a period of a tightened cash flow and fewer awarded contracts because most organizations needed to recheck their plans on capital expenditure. The GCC governments have estimated to award contracts valued at around USD 140bn in 2016, about 15\% decrease when compared to last year's numbers (Salah, 2016).

In MEED report in 2018, it is stated that, for KSA, the fall in revenues in 2015 and 2016 enforced the government to cut its expenditure. This cut had a huge influence on construction and infrastructure expenditure. For example, the budget allocated to transportation and infrastructure sectors fall from $\$ 16.8$ billion in 2015 to almost $\$ 6.3$ billion in 2016, while in Kuwait, with $\$ 234.4$ billion value of active construction projects and \$34 billion value of projects on the concept or design phase, the construction sector in Kuwait is anticipated for growth in spite of the low oil prices especially in oil and gas sector. Of the five major construction projects currently ongoing, four are linked to the oil and gas sector in Kuwait. In addition, the Kuwaiti government is investing $\$ 100$ billion to improve the upstream and downstream facilities efficiencies in its five-year plan 2015-2020.

The annual meeting of the Arab ministers of finance held in 2016 stated that oil and gas sector projects form about thirty-four percent of all project investments in the country. The oil price decline had affected the awarded contracts during the period 2013-2018 in all GCC countries (Deloitte, 2019).

\section{Kuwait Construction Industry}

The building construction industry forms a major part in the State of Kuwait. Construction industry share is $2 \%$ of economic of Kuwait and 4.7\% of the non-oil sector as stated by the Kuwait central statistical office 2008. Construction industry comes as the second part of Kuwait investment after oil sector (AlSanad 2015). In 2019, Kuwait GDP reached $\$ 141.68$ billion, and construction industry contributed about 7\% in Kuwait GDP, and the estimated value of projects in Kuwait is $\$ 447.3$ billion distributed between building, infrastructure, and oil and gas 
sectors (Heijmans, J. 2019). Kuwait construction industry is characterized by existence of megaprojects and multinational workforce.

The Kuwaiti construction industry is exercising major investments in health and housing projects. Country vision 2035 emphasis is on investment in renewing and enhancing performance of educational and infrastructure facilities. The government needs to advance and enhance state's ports, roads, airports, and other related infrastructure facilities (SCPD, 2017).

Kuwait government launched in 2017 a new plan titled Kuwait 2035. This plan aims to establish diversity of governmental income in addition to oil. The plan aims to put the state of Kuwait as an attractive environment for foreign investors in various profitable projects. Regarding construction activities, and due to oil prices drop, a suspension or delay in government investment is expected in project contracts compared to the planned projects, and even for private sector, which depends on banking system project funding. The oil price instabilities have a direct impact on bank system of credits and cash flow. The banking system will take time to absorb or change their policy of project financing and providing credit facilities for local and foreigners contractors. This restricted policy will directly affect the project time performance or even launching new projects. Many financial organizations will be tested as well if there exists a specific threat or risk to loans from the recent decline in the oil price.

\section{METHODOLOGY}

A sufficient revision for literature and earlier research that investigated or studied the influence of lower oil prices on construction progress is done. Many of economical parameters and some of construction characteristics in the construction industry in Kuwait are collected. The economic and financial data are collected from the official web-published reports from Kuwait Central Bank, Kuwait Statistical Bureau, and others. Information collection was aimed toward price movements of basic construction materials from 2007 to 2017 such as steel and cement. The construction materials data were gathered from a number of construction material vendors, construction industry experts, and construction industry financial agencies. The total number of awarded and cancelled public contracts is analyzed during the study period to represent how the oil price affects governmental financing in construction projects. The Ministry of Public Works (MPW) is the major agency that represents the governmental engineer in Kuwait. The number of awarded and cancelled contracts during the study period was collected from its official records. After collecting the needed information, data are statistically analyzed to determine trends of relationship between gathered data elements. SPSS software 24 is used to analyze the data collected. A correlation analysis is conducted to represent the relationship between surveyed elements. The correlation analysis is divided into two stages: the period of oil price stability or price increase from 2007 to 2012 and the period of oil declination from 2013 to 2017 . A regression analysis is done to predict some financial criteria as a result of oil price declination depending on the collected data.

\section{DATA COLLECTION}

Data for Kuwaiti crude oil, several economical parameters, and construction industry essentials are collected for the study period from 2007 to 2017. The selected economic parameters are as follows: GDP values and inflation rates. Steel reinforcement price and ordinary cement price were selected as an example of construction materials. These two elements are chosen because most of the construction building structure systems in Kuwait are made of reinforced concrete. Steel reinforcement and cement are the most influencers for structure system cost. The average cost of construction per square meter is gathered to represent the changes in construction cost during the study period. A number of construction awarded contracts were collected during the study period. The number of awarded contracts was chosen as an indicator of governmental reflection for oil price diversity. 


\section{Kuwaiti Crude Oil Prices}

Kuwait crude oil prices are gathered from the Agency of Kuwait's Central Statistical Bureau (CSB). Figure 1 displays quarterly Kuwaiti oil crude prices for the study period and GDP values for the study period. As shown in Figure 1, Kuwaiti crude oil price reached $34 \mathrm{KD}$ per barrel in 2007 and 2008 before financial recession and then reduced to about $10 \mathrm{KD}$ per barrel in 2016; the Kuwaiti Dinar (KD) is about 3.3 American dollar (\$). Kuwaiti crude oil is almost stable for the period from 2010 to 2013, and it reached about $27 \mathrm{KD}$ per barrel of crude oil. Starting from 2014, the oil price was declined up to 2017, and it ranged between KD 11 and KD 18 per barrel.

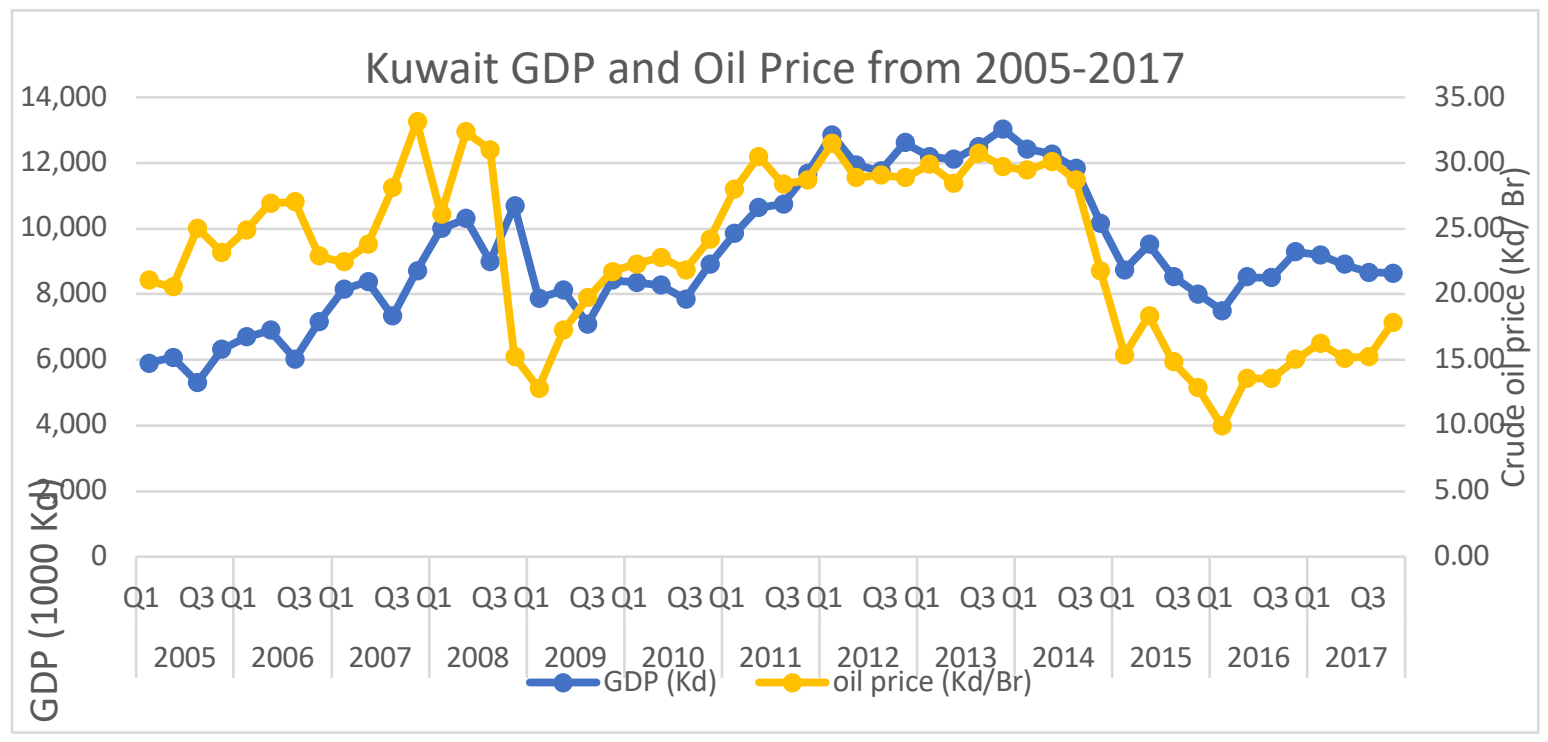

Figure 1. Kuwaiti GDP values and price for Kuwaiti crude oil (KD/Br (2005-2017).

Source: Central Statistical Bureau in Kuwait.

\section{Kuwaiti GDP Values}

Kuwait GDP values were collected from Kuwait Central Bank (KCB) website and CSB publications. Figure 1 shows quarters GDP values in thousands of Kuwaiti Dinars for the period from 2005 till 2017.

\section{Inflation Rates}

Figure 2 shows the quarterly inflation rates in Kuwait from 2008 to 2017. These values are resulting and collected from KCB's web publications. The figure shows that the inflation rates were high during the period of high crude oil price, and then they reduced during the oil price falling period. 


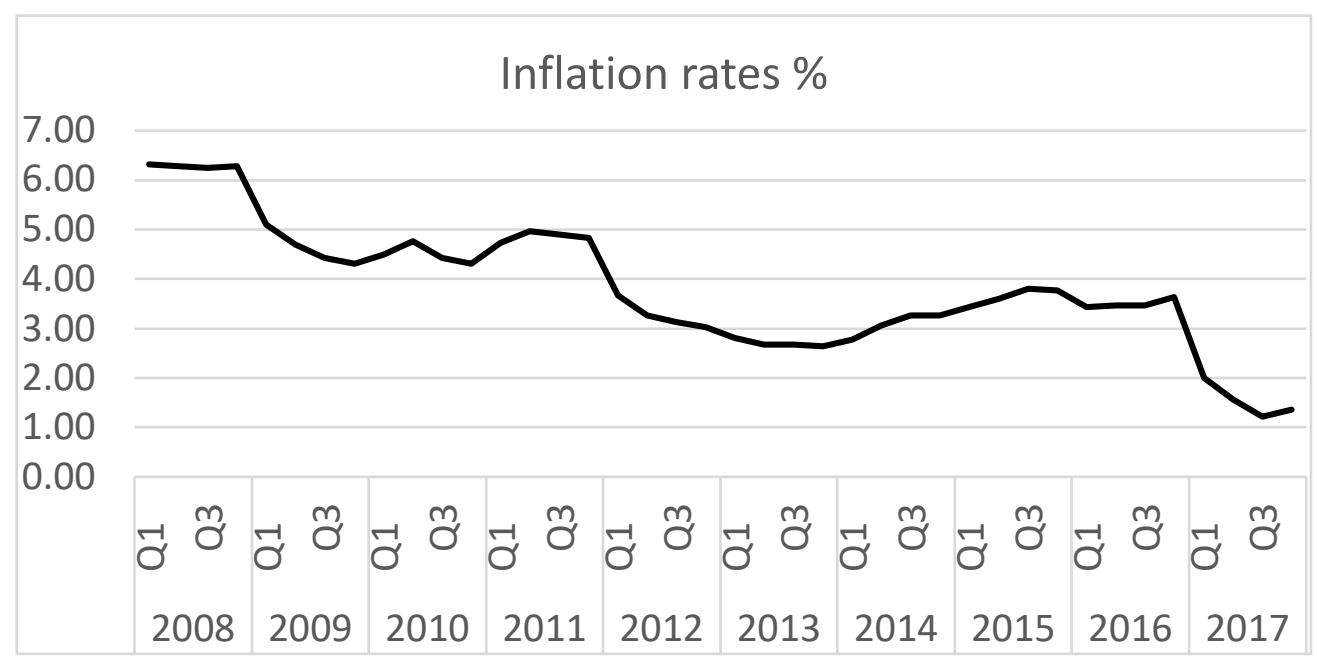

Figure 2. Inflation rates for Kuwait. Source: Central Statistical Bureau in Kuwait.

\section{Steel Reinforcement Price}

Steel reinforcement is one of the costliest elements in concrete construction projects. Most of reinforcement steels used in construction projects in Kuwait are imported from abroad. The price for steel bars of $14 \mathrm{~mm}$ diameter was chosen as a base for comparison. Figure 3 shows quarter steel reinforcement prices for such period. The reinforced steel price for the study period was gathered from recorded data collected from three local contractors and two local steel reinforcement importing vendors.

As can be seen, the steel prices were exaggerated in 2008 directly before the existence of financial crises. After that, it dropped to about $50 \%$ of its price. The fluctuation in steel reinforcement prices was not steeped for the following period.

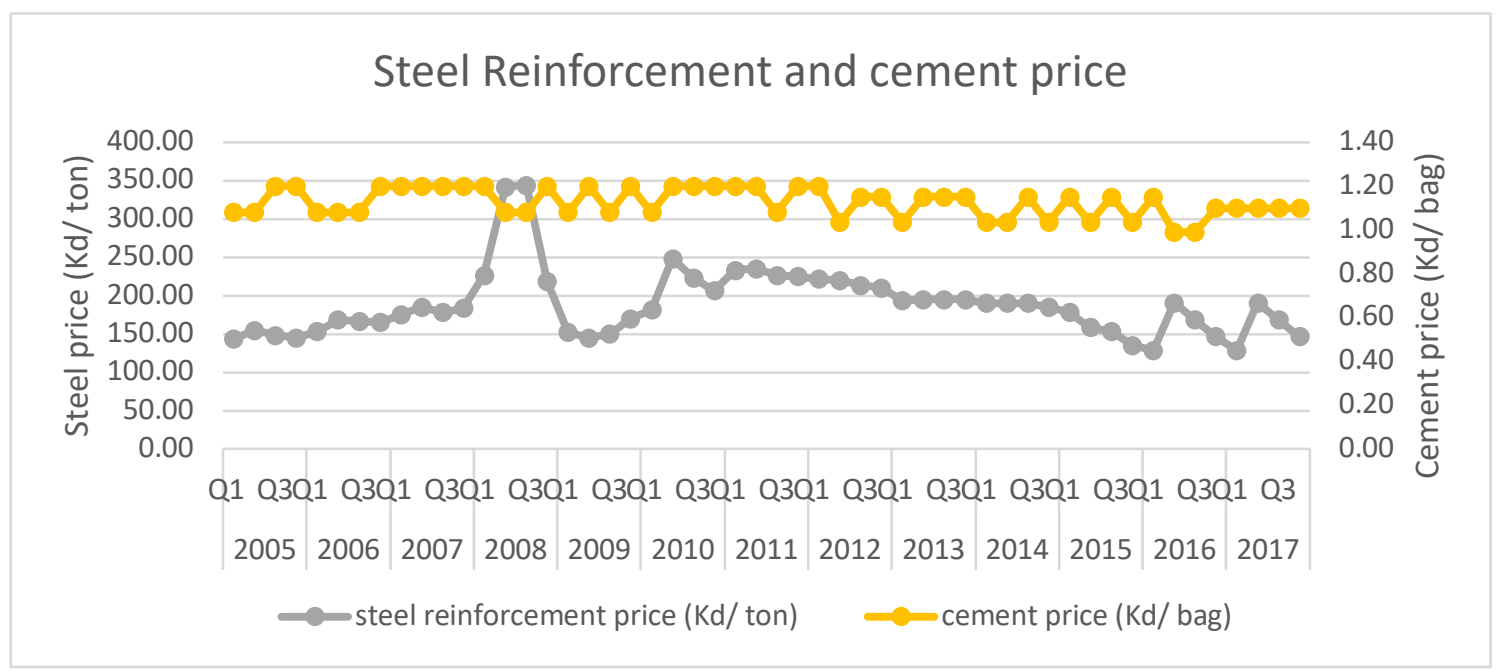

Figure 3. Steel and cement prices in KD for the period from 2005 to 2017.

Source: local steel vendors and general contractors. 


\section{Cement Prices}

Ordinary Portland cement bag $50 \mathrm{~kg}$ was chosen as a base for cement price fluctuation in the study period. As shown in Figure 3, the cement price fluctuates from 1.0 to $1.2 \mathrm{KD} / \mathrm{bag}$ during the study period. Cement prices are collected from historical data gathered from three local contractors and verified from the web site of Kuwait Portland cement company. The variance of cement prices was not remarkable during the study period.

\section{Number and Values for Awarded and Cancelled Contracts}

As shown in the literature, the awarded contracts in the GCC countries were affected by oil price drop. The number of awarded contracts for the ministry of public works in Kuwait was collected. The Ministry of Public Works (MPW) is the official engineer for the Kuwaiti government and is responsible for governmental construction and infrastructure projects in Kuwait. MPW is responsible for the delivery of about $48 \%$ of non-oil and gas governmental construction and infrastructure projects. Awarded contracted numbers were collected from the Ministry of Public Works (MPW) official documents. Figure 4 shows the value of the contract awarded for MPW from 2007 to 2017 in Kuwaiti dinar (KD). Figure 4 shows that the value of awarded contracts is reduced, especially directly after oil price drop starting in 2013. The reduction of awarded value of contracts for years 2013-2015 is remarkable and then increased again after enhancement for the period of 2016-2017. Figure 5 shows the value of awarded contracts categorized by construction sectors. Figure 5 shows that the percentage of money incurred for infrastructure is remarkably increased compared to values of maintenance and building projects. This reflects the governmental policy to concentrate on infrastructure projects instead of new building projects. From MPW official contracts in 2014, five big building contracts were cancelled due to financial shortage.

\section{Values of awarded contracts for MPW 2007-}

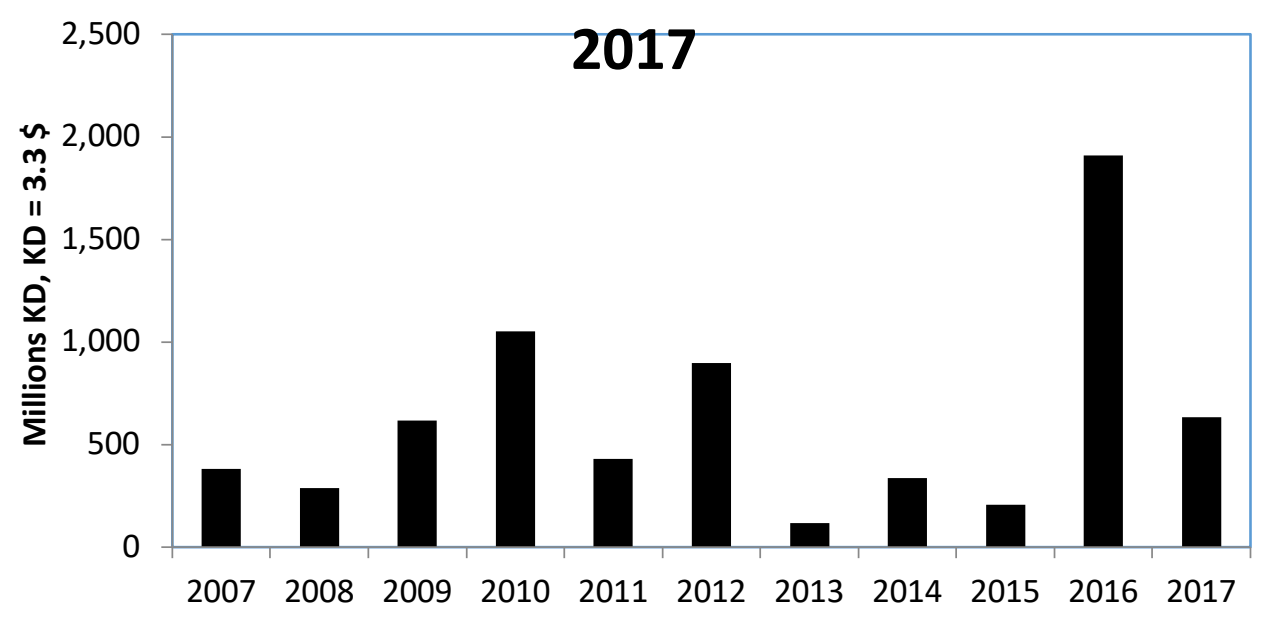

Figure 4. Values of awarded contracts for MPW projects for the period from 2007 to 2017. 


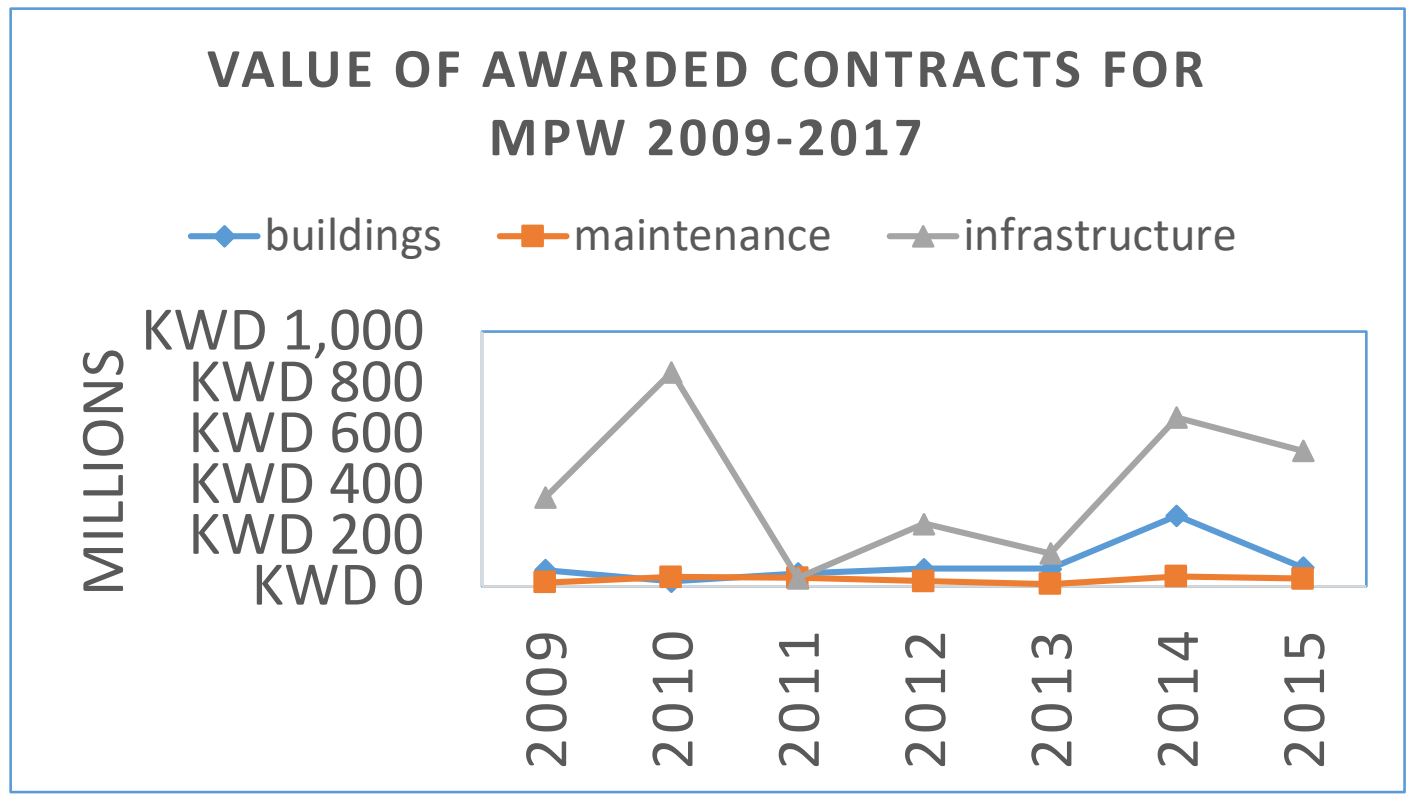

Figure 5. Values of awarded contracts categorized by construction sectors.

\section{DISCUSSION AND RESULTS}

\section{Correlation Analysis}

The statistical analysis software "SPSS 24" was used to calculate correlation coefficient between study variables data. The correlation coefficient may range from a value of $(-1)$ to value of $(+1)$. A higher absolute value of correlation coefficient indicates a stronger relationship between the variables. A correlation rate closer to a value of zero shows no linear relationship between the variables. Table 2 shows Pearson correlation values for Kuwaiti crude oil prices, GDP values, inflation rates, steel reinforcement price, cement prices, and construction cost per square meter during the study period from 2007 to 2017.

Table 2. Pearson correlation values for study parameters from 2007 to 2017.

\begin{tabular}{|c|c|c|c|c|c|c|c|}
\hline \multicolumn{7}{|c|}{ Correlations } \\
\hline \multirow{3}{*}{ oil prices } & oil prices & GDP & $\begin{array}{c}\text { inflation } \\
\text { rates }\end{array}$ & $\begin{array}{c}\text { steel } \\
\text { prices }\end{array}$ & $\begin{array}{c}\text { cement } \\
\text { price }\end{array}$ & $\begin{array}{c}\text { constr. cost } \\
\text { per m2 }\end{array}$ \\
\cline { 2 - 8 } & Correlation & 1 & & & & & \\
\hline \multirow{2}{*}{ GDP } & (2-tailed) Significance & & & & & & \\
\cline { 2 - 9 } & Correlation & $.658^{* *}$ & 1 & & & & \\
\hline quarter inflation & (2-tailed) Significance & .000 & & & & & \\
\hline
\end{tabular}




\begin{tabular}{|c|c|c|c|c|c|c|c|}
\hline \multirow{2}{*}{ rates } & (2-tailed) Significance & .142 & .067 & & & & \\
\hline \multirow{2}{*}{ steel prices } & Correlation & $.634^{* *}$ & $.323^{*}$ & $.460^{* *}$ & 1 & & \\
\cline { 2 - 8 } cement price & (2-tailed) Significance & .000 & .033 & .002 & & & \\
\cline { 2 - 8 } & Correlation & .128 & -.251 & $.480^{* *}$ & .158 & 1 & \\
\hline \multirow{2}{*}{ constr. cost per $\mathrm{m} 2$} & Correlation & $.610^{* *}$ & .268 & $.424^{* *}$ & $.940^{* *}$ & .084 & \\
\cline { 2 - 9 } & (2-tailed) Significance & .000 & .079 & .004 & .000 & .587 & \\
\hline
\end{tabular}

**. Correlation is significant at the 0.01 level (2-tailed).

*. Correlation is significant at the 0.05 level (2-tailed).

As shown in Table 2, most of the variables are significantly correlated. There is a moderate correlation between steel price with each of inflation rates and oil price ( 0.634 and 0.480$)$, and these coefficients are statically significant. There is another moderate correlation between the value of construction cost per meter square with oil price and inflation rates $(0.610$ and 0.424$)$, respectively, and these coefficients are statically significant. The highly recorded correlation coefficient is between construction cost per meter square with the steel reinforcement price (0.940) and the statically significant one. This is not strange as the construction cost mainly depends on steel price, and most of the construction projects in Kuwait are made of concrete structure, which is very sensitive to steel price.

A different analysis for the correlation between the study variables for the period of oil price decline is carried out (2013-2017). Table 3 lists the Pearson correlation values for the same variables for the period of oil prices declining from 2013 to 2017. There is a significant correlation between most of the surveyed variables. Most of the significant alpha are less than 5\%. There is a solid significant correlation between most of the surveyed variables. As shown in Table 3, there is a very strong correlation between oil price and GDP values. The correlation coefficient is 0.986 ; this is not strange as Kuwait is an oil-dependent country, but this is very obvious in this period. This means that the GDP value is strongly declined as oil price dropped, and there is limited effect of most of plans to diverse Kuwait governmental finance. The correlation factor between the price of steel reinforcement and oil price is 0.736 , which indicates a strong relationship between steel reinforcement price and oil price, especially in the oil drop period. The construction cost per meter square has a strong relationship between many of surveyed variables such as oil price, GDP value, and steel price.

\section{Regression Analysis}

It is valuable to use the collected data for the general economic measures and the construction materials prices that are affected by Kuwait oil price fluctuation to predict the construction cost in the oil price declination period. In spite of existence of many factors that affect the construction cost such as equipment cost and manpower cost, the influence of oil price variation in equipment and manpower costs is less than the effect on construction materials. This idea well existed in Kuwait, which depends mainly on oil price for project finance and on importing from abroad for construction material. As mentioned before, most of the gathered data are collected from governmental or international agencies that apply many of data validation methods, so it can be valuable to build a regression model to predict construction cost based on the collected data. 
A regression model is developed using SPSS. Financial variables such as GDP values, oil prices, and inflation rates in addition to construction-related variables, which are steel reinforcement price and cement price, were regressed against the cost of construction per square meter. Table 4 shows the regression analysis using SPSS 24 .

Table 3. Pearson correlation values for study parameters from 2013 to 2017.

\begin{tabular}{|c|c|c|c|c|c|c|c|}
\hline \multicolumn{8}{|c|}{ Correlations } \\
\hline & & $\begin{array}{c}\text { Oil } \\
\text { Prices }\end{array}$ & GDP & $\begin{array}{c}\text { Inflation } \\
\text { Rates }\end{array}$ & $\begin{array}{l}\text { Steel } \\
\text { Prices }\end{array}$ & $\begin{array}{l}\text { Cement } \\
\text { Price }\end{array}$ & $\begin{array}{c}\text { Constr. } \\
\text { Cost Per } \\
\text { M2 }\end{array}$ \\
\hline \multirow{2}{*}{ oil prices } & Correlation & 1 & & & & & \\
\hline & (2-tailed) Significance & & & & & & \\
\hline \multirow{2}{*}{ GDP } & Correlation & $.986^{* *}$ & 1 & & & & \\
\hline & (2-tailed) Significance & .000 & & & & & \\
\hline \multirow{2}{*}{ inflation rates } & Correlation & -.119 & -.086 & 1 & & & \\
\hline & (2-tailed) Significance & .617 & .718 & & & & \\
\hline \multirow{2}{*}{ steel prices } & Correlation & $.736^{* *}$ & $.712^{* *}$ & -.110 & 1 & & \\
\hline & (2-tailed) Significance & .000 & .000 & .643 & & & \\
\hline \multirow{2}{*}{ cement price } & Correlation & .022 & -.012 & .253 & .144 & 1 & \\
\hline & (2-tailed) Significance & .925 & .960 & .283 & .546 & & \\
\hline \multirow{2}{*}{$\begin{array}{l}\text { constr. cost } \\
\text { per } \mathrm{m} 2\end{array}$} & Correlation & $.749^{* *}$ & $.732^{* *}$ & -.195 & $.780^{* *}$ & -.081 & 1 \\
\hline & (2-tailed) Significance & .000 & .000 & .410 & .000 & .734 & \\
\hline
\end{tabular}

**. Correlation is significant at the 0.01 level (2-tailed).

The model coefficients ( $\mathrm{R}, \mathrm{R}$ square, and adjusted $\mathrm{R}$ square) are given as $0.870,0705$, and 0.6 , respectively. This indicates that the model is about $75 \%$ fit. and the significant alpha value of ANOVA is 0.002 , which is less than $5 \%$. The mathematical model can be expressed by the following equation:

$\mathrm{CS}=35.294+0.175(\mathrm{OP})+1.1518 * 10^{-7}(\mathrm{GDP})-0.605(\mathrm{IR})+0.21(\mathrm{SP})-22.309(\mathrm{CP}) \ldots \ldots(1)$ where $\mathrm{CS}$ is the construction cost per square meter $(\mathrm{KD} / \mathrm{m} 2)$, OP is the oil price in $\mathrm{KD}$, GDP is the quarterly GDP in KD, IR is the inflation rate, $\mathrm{SP}$ is the steel reinforcement price per ton in $\mathrm{KD}$, and $\mathrm{CP}$ is the cement price per ton in $\mathrm{KD}$. 
Table 4. Regression analysis for construction cost in Kuwait during oil price drop period.

\begin{tabular}{|c|c|c|c|c|c|c|c|c|c|}
\hline \multicolumn{2}{|c|}{ Model Summary } \\
\hline \multirow{2}{*}{ Model } & $\mathrm{R}$ & R-square & $\begin{array}{c}\text { Adjusted } \\
\text { R-square }\end{array}$ & $\begin{array}{c}\text { Std. Err. of } \\
\text { Estimate }\end{array}$ & $\begin{array}{c}\text { R-Square } \\
\text { Change }\end{array}$ & F-Change & df1 & df2 & $\begin{array}{c}\text { Sig. F } \\
\text { Change }\end{array}$ \\
\hline 1 & $.840^{\mathrm{a}}$ & .705 & .600 & 5.95751 & .705 & 6.689 & 5 & 14 & .002 \\
\hline
\end{tabular}

a. Predictors: (Constant), cement price q, GDP quarter, quarter inflation rates, steel prices Q, oil prices Q

\begin{tabular}{|c|c|c|c|c|c|c|}
\hline \multicolumn{7}{|c|}{ ANOVA } \\
\hline \multirow{2}{*}{ Model } & sum of squares & df & Mean square & F & Sig. \\
\hline \multirow{3}{*}{1} & Regression & 1187.016 & 5 & 237.403 & 6.689 & $.002^{\text {b }}$ \\
\cline { 2 - 7 } & Residual & 496.887 & 14 & 35.492 & & \\
\cline { 2 - 7 } & Total & 1683.903 & 19 & & & \\
\hline
\end{tabular}

a. (Dependent Variable): constr. cost per $\mathrm{m} 2$

b. Predictors: (Constant), cement price q, GDP quarter, quarter inflation rates, steel prices Q, oil prices Q

\begin{tabular}{|c|c|c|c|c|c|c|}
\hline \multicolumn{7}{|c|}{ Coefficients } \\
\hline & \multirow{2}{*}{ Model } & \multicolumn{2}{|c|}{ Unstandardized Coefficients } & \multirow{2}{*}{$\begin{array}{c}\begin{array}{c}\text { Standardized } \\
\text { Coefficients }\end{array} \\
\text { Beta }\end{array}$} & \multirow{2}{*}{$\mathrm{t}$} & \multirow{2}{*}{ Sig. } \\
\hline & & $\mathrm{B}$ & Std. Error & & & \\
\hline \multirow{6}{*}{1} & (Constant) & 35.294 & 37.263 & & .947 & .360 \\
\hline & oil prices Q & .175 & .368 & .448 & .476 & .641 \\
\hline & GDP quarter-kd & $-1.518 \mathrm{E}-7$ & .000 & -.098 & -.107 & .916 \\
\hline & quarter inflation rates & -.605 & 1.853 & -.051 & -.326 & .749 \\
\hline & steel prices Q & .210 & .086 & .537 & 2.446 & .028 \\
\hline & cement price q & -22.309 & 22.612 & -.156 & -.987 & .341 \\
\hline
\end{tabular}

a. Dependent Variable: constr. cost per $\mathrm{m} 2$

As shown in Table 4, the ANOVA significant value is 0.002 , which is less than 0.05 , indicating that the prediction is significant based on surveyed variables, and the overall regression model is significant. 
This model can be used to estimate the construction costs in Kuwait construction industry during oil price drop periods.

\section{CONCLUSION AND RECOMMENDATION}

The State of Kuwait is an oil-dependent country. More than $90 \%$ of its annual income is coming from oil production. After starting oil price reduction in 2013, the construction industry in Kuwait is remarkably affected. In this study, many of the collected data regarding economical parameters and construction materials were gathered during the period from 2007 to 2017 to distinguish the difference between the periods of oil price variance.

Data for Kuwait crude oil, GDP value, inflation rates, steel reinforcement price, construction cost per square meter, ordinary cement, and the value of awarded contracts during the study period were collected. All collected data are gathered from official documentation and official websites of official agencies in Kuwait such as statistical bureau, Kuwait central bank, and others and by direct contacts with construction material vendors and professional contractors in Kuwait.

The collected data are correlated and analyzed, and the correlation factors for the variable data are significant between oil price and GDP values and between steel reinforcement price and oil price. These correlation factors between study variables became more strongly correlated for oil price drop period (2013-2017).

A regression model is proposed to predict the construction cost per square meter based on values of gathered variables during the period of oil price decline. The regression model can be used to predict the construction cost value in Kuwaiti dinar per square meter in case of oil price declination.

The research revealed that Kuwait construction projects are significantly affected by oil price fluctuation. This influence was in the value and type of new projects during the study period, especially after the period of oil drop.

Many recommendations should be provided to Kuwait government as a result of its dependance on oil exports for financing projects. One of these recommendations is to reschedule construction projects in the current plan 2035. The proposed rescheduling should take into consideration the importance of each project to the strategic plan, project budget, effect on public, oil price prediction, etc.

The study showed that a limited success of economic diversification in Kuwait and link to the governmental project financing to oil exports revenue is not preferable during the coming years. There is an urgent need for economic diversification and encouraging the private sector to share in financing governmental projects.

\section{FUTURE RESEARCH WORK}

The regression model results will be verified by Mont Carlo simulation application and by applying in actual data.

\section{ACKNOWLEDGMENT}

The authors acknowledge the support of Kuwait University's Research Administration for funding this research through research grant EV02/16. 


\section{REFERENCES}

AlSanad, S. 2015. Awareness, Drivers, Actions, and Barriers of Sustainable Construction in Kuwait. Procedia Engineering 118, $969-983$

Al-Zayani, A. B. R. 2012. Statistical Bulletin. In: Department, I. S.-S. (ed.). The Cooperation Council for The Arab States of Gulf Secretariat General.

Annual Meeting of Arab Ministers of Finance. 2016, https://www.imf.org/external/np/pp/eng/2016/042916.pdf

Central Bank of Kuwait. http://www.cbk.gov.kw/ar/

Cherif, R., Hasanov, F. 2014. Soaring of the Gulf Falcons: diversification in the GCC oil exporters in seven propositions. International Monetary Fund, IMF Working Paper, WP/14/177.

CSB, C. S. B. 2012. Revised and Provisional Estimates State of Kuwait: Central Statistical Bureau.

Deloitte. 2018. Has the industry turned the corner? Deloitte GCC Powers of Construction 2018

General Secretariat of the Supreme Council for Planning and Development - https://www.scpd.gov.kw/

Heijmans, J. 2019. Kuwait in transition: towards a post-oil economy. International Building \& Construction Show, Dubai: DMG Events. (pp. 1-43).

Hwang. 2013. The impact of oil price fluctuation on the Singapore construction industry. Int. J. Project Organization and Management, Vol. 5, No. 3, 265-278.

Institute of Banking Studies. 2015. What is the Impact of Lower Oil Prices in Kuwait and on the Kuwaiti Banks", a Special report by the Institute of Banking Studies in Kuwait.

International Monetary Fund IMF. 2019. IMF special report. Executive Board Concludes 2019 Article IV Consultation with Kuwait.

M. Hvidt. 2013. Economic Diversification in GCC Countries: Past Record and Future Trends. Research. Kuwait Program on Development, Governance and Globalization in the Gulf States. London School of Economics and Political Science, London.

MEED report. 2018. https://www.meed.com/a-tale-of-two-markets-construction-oil-and-gas/

Okoye, P.U, Ngwu, C., Ezeokoli, F.O. and Ugochukwu, S.C. 2016. Imperatives of Economic Fluctuations in the Growth and Performance of Nigeria Construction Sector. Microeconomics and Macroeconomics 2016, 4(2): 46-55

Okoye, P.U., Mbakwe, C.C. and Igbo, E. N. 2018. Modeling the Construction Sector and Oil Prices toward the Growth of the Nigerian Economy: An Econometric Approach. Economies, 6, 16

Olanrewaju O.I., Idiake J.E., Oyewobi, L.O. and Akanmu W.P. 2018. Global Economic Recession: Causes and Effects on Nigeria Building Construction Industry Journal of Surveying, Construction and Property (JSCP) vol 9, issue 1 pp 9-18

Olatunji, O.A. 2015. The impact of oil price regimes on construction cost in Nigeria, Construction Management and Economics. 28, 7, 747-759

Osigwe, A. 2015. The Impact of Oil Resource Abundance on Building and Construction Investment in Nigeria. International Journal of Economics and Society, Issue 1, 14-17

PWC report. 2016. https://www.pwc.com/m1/en/publications/documents/cpi-survey-delivering-during-change2016.pdf

Rowland, Christopher S., and James W. Mjelde. 2016. Politics and Petroleum: Unintended Implications of Global Oil Demand Reduction Policies. Energy Research \& Social Science 11, 209-224. 
Salah A. N. 2016. The effects of oil price shocks on the economies of the Gulf Co-operation Council countries: Nonlinear analysis. Energy Policy 91, 256-267.

Shaari, M., Lee Pei, T. and Abdul Rahim, H. 2013. Effects of Oil Price Shocks on the Economic Sectors in Malaysia. International Journal of Energy Economics and Policy Vol. 3, No. 4, 2013, pp.360-366 SPSS software.

Thorbecke, W. 2019. How oil prices affect East and Southeast Asian economies: Evidence from financial markets and implications for energy security. Energy Policy, Vol 128, 3, Pages 628-638 